\title{
The impact of coarse aggregate shape on the behavior of self-compacting high-performance concrete
}

\author{
Krzysztof Ostrowski ${ }^{1, *}$ \\ ${ }^{1}$ Faculty of Mining and Geoengineering, AGH University of Science and Technology, Cracow, Poland
}

\begin{abstract}
Self-Compacting High Performance Concrete (SCHPC) presents a crucial step in the development of concrete technology. The most important features of self-consolidating concrete are flowability, segregation resistance and passing ability. Generally, the rheological properties are modified by effective superplasticisers and water to binder ratio. The aim of this study is to focus on the important aspect of the impact of shape of the coarse aggregate on fresh concrete mixture properties, strength and deformability of SCHPC. Coarse aggregate is a significant proportion of the concrete volume and therefore has a meaningful influence on its quality. By appropriate selection of the shape of the grain aggregate, it is possible to affect the rheological parameters of concrete. The results presented in this study indicated that the shape of the grains of coarse aggregate has an impact on the strength and stiffness of SCHPC. Moreover, the occurrence of irregular grains of coarse aggregate causes lower slump flow and higher plastic viscosity in comparison to concrete mixtures with regular grains only. The research presented in this article is part of the author's wider research devoted to this issue.
\end{abstract}

\section{Introduction}

In recent years, an increase of the interest in the use of self-compacting concrete (SCC) in civil engineering is has been noticed. This technology is still developing and being considered for a wider range of applications and properties of concrete [1]. The ability to consolidate under its own weight of concrete mixture without any means of compaction is a characteristic of SCC. Due to using small size aggregate and flowability of concrete mixture, SCC spreads fluently around reinforcement [2-5]. It is worth noting that nowadays cement paste content and water to binder ratio are the most significant parameters of the mix design which influences rheological parameters and strength of concrete. Nevertheless mixed design methods are still being developed [6-8].

The quality of the aggregate is determined by grain composition and grain shape, which significantly affects its strength. The content of irregular grains in mineral aggregates depends mainly on the method of crushing the raw material, i.e. on the type of grinding equipment used, their construction and operating parameters, the degree of fragmentation and the number of crushing stages [9]. Bearing this in mind, the purpose of this study was to appraise the effect of coarse aggregate shape on the properties of SCHPC.

* Corresponding author: kostrow@agh.edu.pl 


\section{Materials and methods}

Details of the concrete mixtures used in the study were presented in Table 1. The constituent of concrete mixture were as follows: Portland-fly ash Cement type I - CEM I 52.5R (Górażdże, Poland), fine sand $\phi 0-2 \mathrm{~mm}$ (Brzegi, Poland), separated granite $\phi 4-8 \mathrm{~mm}$ (Kamienna Góra, Poland), SikaFume additive, superplasticiser Sika ViscoCrete-20 HE, 0.28 water/binder ratio.

Table 1. Proportions of concrete mixture ingredients.

\begin{tabular}{|c|c|c|c|c|c|c|c|}
\hline $\begin{array}{l}\text { Mix } \\
\text { type }\end{array}$ & $\begin{array}{l}\text { Cement } \\
{\left[\mathrm{kg} / \mathrm{m}^{3}\right]}\end{array}$ & $\begin{array}{c}\text { Fine } \\
\text { aggregate } \\
{\left[\mathrm{kg} / \mathrm{m}^{3}\right]}\end{array}$ & $\begin{array}{c}\text { Coarse } \\
\text { aggregate-regular } \\
\text { grains } \\
{\left[\mathrm{kg} / \mathbf{m}^{3}\right]}\end{array}$ & $\begin{array}{c}\text { Coarse } \\
\text { aggregate-irregular } \\
\text { grains } \\
{\left[\mathbf{k g} / \mathbf{m}^{3}\right]}\end{array}$ & $\begin{array}{c}\text { Sika } \\
\text { Fume } \\
{\left[\mathrm{kg} / \mathrm{m}^{3}\right]}\end{array}$ & $\begin{array}{l}\text { Water } \\
{\left[\mathrm{kg} / \mathrm{m}^{3}\right]}\end{array}$ & $\begin{array}{c}\text { Superplas } \\
\text {-ticiser } \\
{\left[\mathrm{kg} / \mathrm{m}^{3}\right]}\end{array}$ \\
\hline $\mathrm{C}$ & 550 & 850 & 475 & 475 & 66 & 173 & 19.25 \\
\hline E & 550 & 850 & 950 & - & 66 & 173 & 19.25 \\
\hline
\end{tabular}

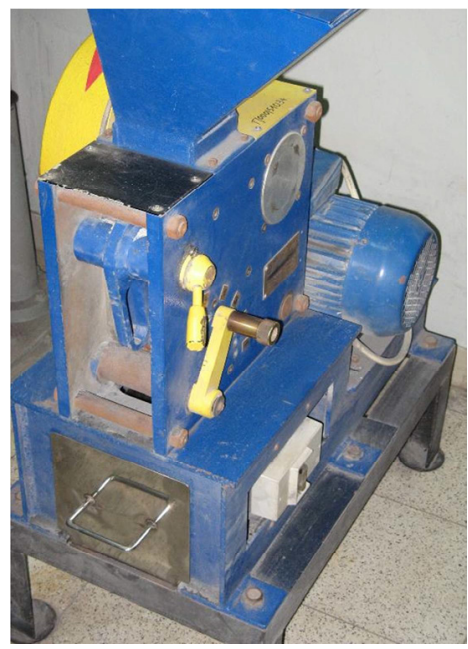

Fig. 1. Laboratory jaw crusher.

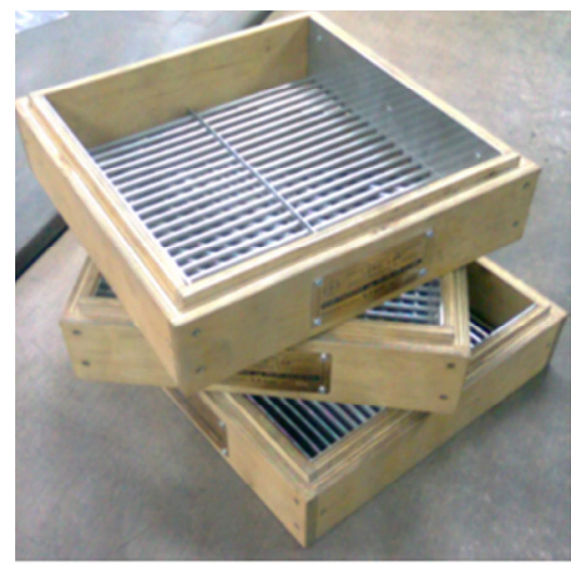

Fig. 2. Slotted sieves.

A jaw crusher was used to prepare the coarse aggregate (Fig. 1). The feed material which was subjected to a process of shredding was granite $(\phi 20-150 \mathrm{~mm})$. In order to receive regular and irregular grains, resulting product was correctly separated by using slotted sieves (Fig. 2) in accordance with [10].

The following narrow size fractions were extracted: $4-5 \mathrm{~mm}, 5-6.3 \mathrm{~mm}$ and $6.3-8 \mathrm{~mm}$. This fractions were separated by using sieves with spacing between bars $2.5 \mathrm{~mm}, 3.15 \mathrm{~mm}$, $4 \mathrm{~mm}$, respectively. The upper products on the slotted sieve are regular grains, the lower irregular grains (Fig. 3).

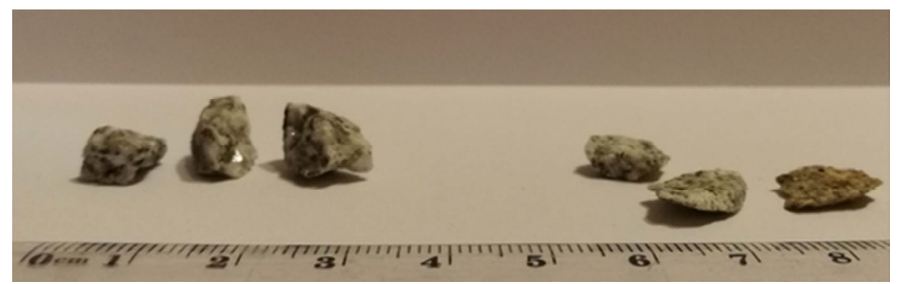

Fig. 3. Regular (left) and irregular grains (right) of coarse aggregate. 
The study used grain sizes of $\phi 4-8 \mathrm{~mm}$ only. The bulk density of coarse aggregate is $\rho \mathrm{a}=2.64 \mathrm{~g} / \mathrm{cm}^{3}$. Sieve analysis of coarse aggregate is shown in Table 2.

Table 2. Sieve analysis of coarse aggregate.

\begin{tabular}{|c|c|c|}
\hline \multicolumn{3}{|c|}{ Granite coarse aggregate $\boldsymbol{\phi} \mathbf{4 - 8} \mathbf{~ m m}$} \\
\hline Granulation & $\begin{array}{c}\text { Regular coarse aggregate } \\
{[\%]}\end{array}$ & $\begin{array}{c}\text { Irregular coarse aggregate } \\
{[\%]}\end{array}$ \\
\hline $4-5$ & 27.23 & 42.35 \\
\hline $5-6.3$ & 26.37 & 32.60 \\
\hline $6.3-8.0$ & 46.40 & 25.05 \\
\hline
\end{tabular}

The only variable in the conducted research was the shape of the coarse aggregate. A total of 24 cylindrical specimens $(118 \mathrm{~mm}$ in height and $59 \mathrm{~mm}$ in outer diameter) were manufactured in a laboratory and tested under uniaxial compression. With each type of concrete mixtures were made twelve specimens; four of them were tested after 3 (C1-C4, E1-E4), 7 (C5-C8, E5-E8) and 28 days. The concrete specimens were ripened in a water bath with a temperature of $20^{\circ} \mathrm{C}$. In this article selected research for two concretes $(\mathrm{C}, \mathrm{E})$, tested after 3 and 7 days were shown.

The characteristics of fresh concrete mixtures were tested by using a slump flow test, in line with [11]. Plastic viscosity was determined in the moment to reach a diameter of $500 \mathrm{~mm}$ by flowing concrete mixture. The density of concrete was determined by dividing the mass by the volume of specimens. The compression tests were performed using a 3,000 kN capacity walter+bai ag Testing Machine with the constant axial strain rate of the samples in all of the experiments being approximately $3 \times 10^{-5}\left[\mathrm{~s}^{-1}\right]$, at air temperature of $20^{\circ} \mathrm{C}$ and humidity of $60 \%$. The measurement of the axial force was carried out by means of a force transducer, whereas the displacements were estimated by extensometer. Axial and radial displacements were determined through the measurement of the whole specimens' dimension changes, where the extensometer were mounted directly between compression plates. Arrangement of extensometers on the specimens is shown at Figure 4.
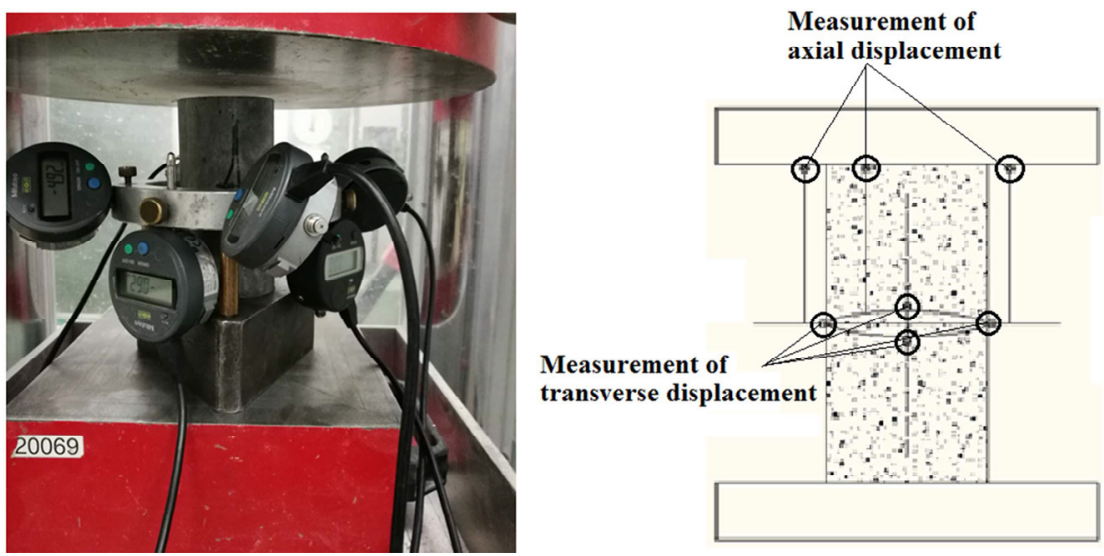

Fig. 4. Arrangement of extensometers on the specimens.

\section{Selected test results and discussion}

Figure 5 presents rheological parameters of concrete mixtures. It should be noted that concrete mixture with regular grains only (E), has higher slump flow than mixture with $50 \%$ irregular grains content $(\mathrm{C})$. Moreover, plastic viscosity is higher when using both 
regular and irregular grains in concrete mixtures. Confirmation of the correct execution of concrete mixtures is the lack of leakage of cement paste in all concrete mixtures. What is more, separation of the components did not occur. During the flow of the mixtures, proper venting was observed.

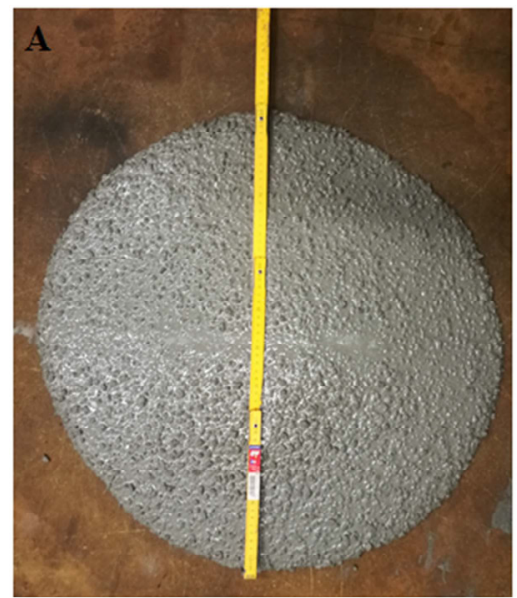

$\mathrm{T}_{500}=11.7[\mathrm{~s}] \mathrm{SF}=620 \mathrm{~mm}$

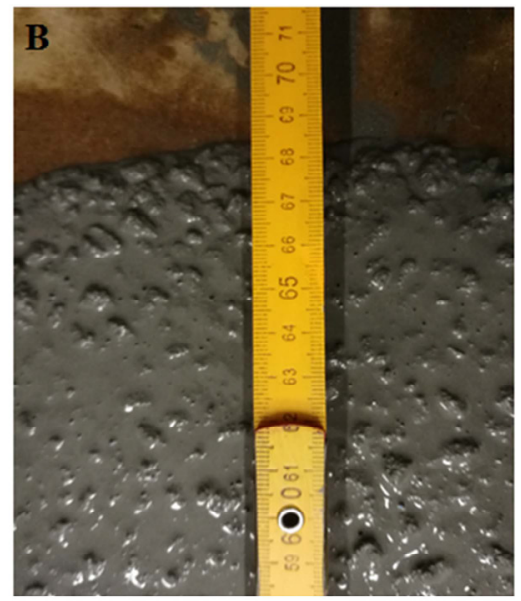

$\mathrm{T}_{500}=4.5[\mathrm{~s}] \mathrm{SF}=690 \mathrm{~mm}$

Fig. 5. Slump Flow test for C (A) and E (B) concrete mixture.

Research indicates the important role of the coarse aggregate shape on the mechanical properties of concretes (Table 3). Average compressive strength of concrete $\mathrm{C}$ in comparison to concrete $\mathrm{E}$ is higher by $14.4 \%$ and $23.9 \%$ after 3 and 7 days, respectively. Elasticity of concrete - the Young modulus (E) was determined without preloading cycles in a range of stress ranging from $15 \%$ to $33 \%$ value of maximum stress, therefore results are qualitative [12]. The use of aggregate with irregular grains leads to higher stiffness of concrete. Average Young modulus in case concrete $\mathrm{C}$ is higher by $26.3 \%$ and $16.8 \%$ after 3 and 7 days in collation to concrete E.

Table 3. Selected physical and mechanical properties of tested concretes.

\begin{tabular}{|c|c|c|c|c|c|}
\hline $\begin{array}{c}\text { Mix } \\
\text { type }\end{array}$ & $\begin{array}{c}\text { Density of } \\
\text { concrete } \\
{\left[\mathbf{k g} / \mathbf{m}^{\mathbf{3}}\right]}\end{array}$ & $\begin{array}{c}\text { Average } \\
\text { compressive } \\
\text { strength at 3 days } \\
\overline{\boldsymbol{R}}_{\boldsymbol{c}}[\mathbf{M P a}]\end{array}$ & $\begin{array}{c}\text { Average } \\
\text { compressive } \\
\text { strength at 7 days } \\
\overline{\boldsymbol{R}}_{\boldsymbol{c}}[\mathbf{M P a}]\end{array}$ & $\begin{array}{c}\text { Average } \\
\text { Young modulus } \\
\text { at 3 days } \\
\overline{\boldsymbol{E}} \text { [GPa] }\end{array}$ & $\begin{array}{c}\text { Average } \\
\text { Young modulus } \\
\text { at 7 days } \\
\overline{\boldsymbol{E}} \text { [GPa] }\end{array}$ \\
\hline $\mathrm{C}$ & 2396 & 68.63 & 83.08 & 18.30 & 20.82 \\
\hline $\mathrm{E}$ & 2398 & 59.97 & 67.05 & 14.49 & 17.82 \\
\hline
\end{tabular}

Detailed results for each sample are shown in Table 4. It is worth pointing out that concrete $\mathrm{C}$ has lower values of standard deviations in case of compressive strength and Young modulus in comparison to concrete E, where we can observe a greater heterogeneity of results (Fig. 6).

Figure 7 presents typical failure modes of concrete specimens. Due to the method of testing (constant axial strain rate) and to stop the compression test after reaching the maximum compressive strength, sudden destruction of the samples was not observed. 
Table 4. Summary of the experimental results.

\begin{tabular}{|c|c|c|c|c|c|c|c|}
\hline $\begin{array}{l}\text { Group of } \\
\text { specimens }\end{array}$ & $\begin{array}{l}\text { Speci- } \\
\text { men }\end{array}$ & $\begin{array}{c}\text { Ultimate } \\
\text { load } \\
P_{\max }[\mathrm{kN}]\end{array}$ & $\begin{array}{c}\text { Nominal } \\
\text { compressive } \\
\text { strength } \\
\mathbf{R}_{\mathbf{c}}[\mathrm{MPa}] \\
\end{array}$ & $\begin{array}{c}\text { Standard } \\
\text { deviation } \\
\text { s[MPa] }\end{array}$ & $\begin{array}{c}\text { Axial strain } \\
\text { during } \\
\text { fracture } \\
\varepsilon[\%,] \\
\end{array}$ & $\begin{array}{c}\text { Modulus of } \\
\text { elasticity } \\
\text { E [GPa] }\end{array}$ & $\begin{array}{r}\text { Standard } \\
\text { deviation } \\
\text { s[GPa] }\end{array}$ \\
\hline \multirow{8}{*}{$\mathrm{C}$} & $\mathrm{C} 1$ & 168 & 62.29 & \multirow{4}{*}{7.19} & 3.18 & 17.30 & \multirow{4}{*}{0.76} \\
\hline & $\mathrm{C} 2$ & 178 & 66.26 & & 4.50 & 19.00 & \\
\hline & $\mathrm{C} 3$ & 180.1 & 67.01 & & 4.02 & 18.78 & \\
\hline & $\mathrm{C} 4$ & 212.2 & 78.95 & & 4.56 & 18.14 & \\
\hline & $\mathrm{C} 5$ & 220 & 81.90 & \multirow{4}{*}{2.68} & 4.42 & 18.87 & \multirow{4}{*}{1.70} \\
\hline & C6 & 215 & 79.99 & & 4.17 & 21.23 & \\
\hline & C7 & 231.3 & 86.10 & & 4.18 & 22.92 & \\
\hline & C8 & 226.5 & 84.32 & & 4.38 & 20.27 & \\
\hline \multirow{8}{*}{ E } & E1 & 130 & 48.53 & \multirow{4}{*}{8.38} & 4.00 & 13.94 & \multirow{4}{*}{3.23} \\
\hline & E2 & 168 & 62.72 & & 4.52 & 14.15 & \\
\hline & E3 & 184 & 68.46 & & 3.61 & 18.83 & \\
\hline & E4 & 162.3 & 60.18 & & 4.85 & 11.02 & \\
\hline & E5 & 225.3 & 83.87 & \multirow{4}{*}{12.09} & 4.01 & 21.96 & \multirow{4}{*}{2.82} \\
\hline & E6 & 182.2 & 67.83 & & 3.97 & 16.40 & \\
\hline & E7 & 156 & 58.07 & & 3.51 & 17.16 & \\
\hline & E8 & 157 & 58.44 & & 3.40 & 15.75 & \\
\hline
\end{tabular}
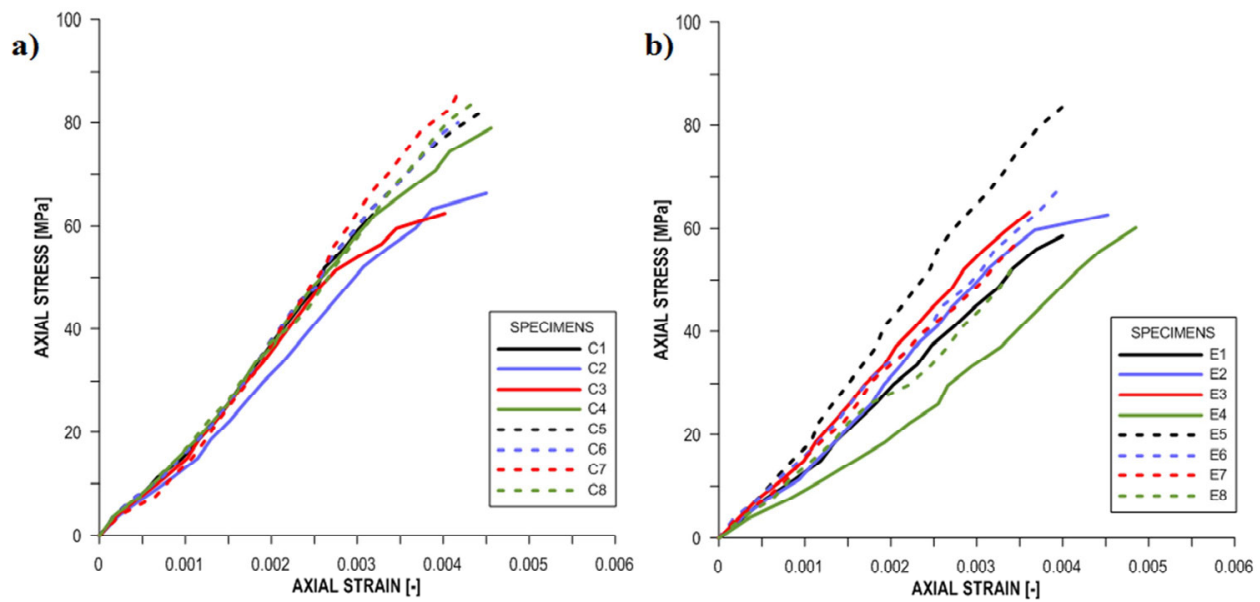

Fig. 6. Axial stress-strain relationships for tested concretes: a) C, b) E.

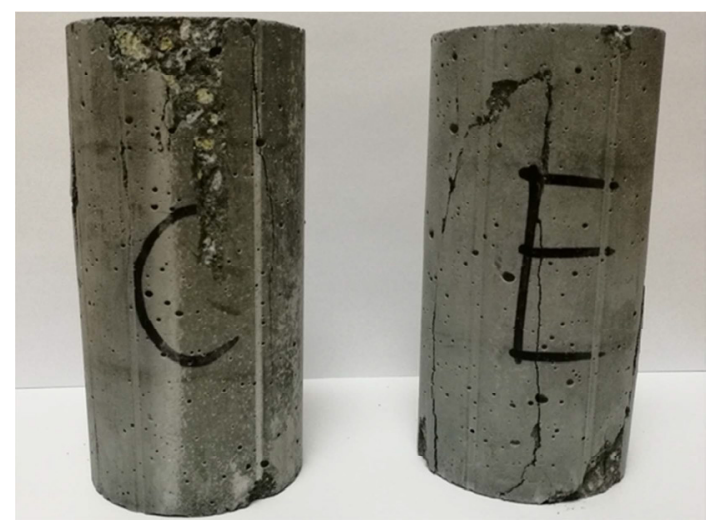

Fig. 7. Typical failure modes for tested concretes $\mathrm{C}$ and $\mathrm{E}$. 


\section{Summary and perspectives}

This paper shows an experimental investigation of the influence of coarse aggregate shape on the properties of self-compacting high-performance concrete. The following conclusions may be drawn from the work presented in this work:

1) The shape of the grains of coarse aggregate has a significant impact to strength and stiffness of self-compacting, high-performance concretes.

2) Additive of irregular grains of coarse aggregate may causes better filling of grain skeleton. The sharper edges of this grains may cause stress concentrations, what could lead to increased compressive strength.

3) Flowability of concrete mixtures depends on shape of coarse aggregate.

4) Appropriate selection of the shape of the grains of coarse aggregate allow us to affect the rheological parameters of concrete.

The future work will focus on assessing the effect of coarse aggregate shape on the structure of pores, hardness and microstructure of modified SCHPC. It could be helpful to recognize this phenomenon in details.

\section{References}

1. K. Ostrowski, (The influence of coarse aggregate shape on the properties of highperformance, self-compacting concrete. Technical Transaction, Civil Engineering., 5, 25-33, 2017)

2. A. Mohan, K. M. Mini, Constr. Build. Mater., 171, 919-928 (2018)

3. G. Barluenga, C. Guardia, J. Puentes, Constr. Build. Mater., 167, 235-242 (2018)

4. M. Tabatabaeian, A. Khaloo, A. Joshaghani, E. Hajibandeh, Constr. Build. Mater., 147, 497-509 (2017)

5. M. Kaszyńska, Cem. Concr. Compos., 24, 253-261 (2002)

6. A. Kostrzanowska-Siedlarz, J. Gołaszewski, Constr. Build. Mater., 115, 705-715 (2016)

7. Ł. Sadowski, Appl. Sci., 7, 893, 2017

8. Ł. Sadowski, T.G. Mathia, Constr. Build. Mater., 113, 613-621 (2016)

9. T. Gawenda,Mining Science - Mineral Aggregates., 22, 45-59 (2015)

10. BS EN 933-4:2008, Tests for geometrical properties of aggregates. Determination of particle shape. Shape index, (2009)

11. EN 12350-8:2009, Testing fresh concrete - Part 8: Self-compacting concrete - Slump flow test (2009)

12. EN 12390-13:2013, Testing hardened concrete, Part 13: Determination of secant modulus of elasticity in compression (2013) 